\title{
The Environmentalist and Development Value Paradox in Bangladesh: Case of Rampal Power Plant and the 'Save Sundarbans' Movement
}

Fahima Al Farabi*

\begin{abstract}
From the past decade, Bangladesh has shown a strong drive toward economic growth and in the process of achieving the related goal of becoming a middle-income country, it has adopted a power system plan that is heavily dependent on fossil fuels. As a result, there was a certain plan to build several coal powered plants, among which the most debated remains the plant initiated near the largest mangrove forest in the country, the Sundarbans. This power plant, called the Rampal power plant, has seen the emergence of a strong urban environmental movement resisting it. The anti-Rampal or 'Save Sundarbans' movement showcases the environment versus development discourses elaborately, with each side- the government and the environmental activists advancing their respective arguments supporting or opposing the plant under construction. This paper attempts to view these arguments through the lens of value theories, i.e. what are the values of either parties regarding the power plant and how they uphold these values. In a related vain, the environmentalist approach(s) of the movement are analyzed, as well as the development centered values of the stateare analyzed within the energy/power sector context. Methods of critical discourse analysis were applied to analyze the public debate that ensued regarding the power plant.
\end{abstract}

Keywords: Environmentalism, Development, Values, Energy, Sundarbans

\section{Introduction}

As of the twenty-first century, our age has been called 'Anthropocene'- a time when human-induced changes in the environment are slowly shifting the earth's climate toward a more unstable condition, making human beings one of the major agents of geological change. The force of this nomenclature has been felt strongly in the academia and environmental discourses worldwide, with scholars in diverse disciplines of the humanities and social sciences citing the term in their analysis of the new realities emerging under the auspices of climate change. In delving into the issues that Anthropocene brings forth,

*Mrs. Farabi is an Assistant Professor of Anthropology, Jahangirnagar University, Bangladesh 
academics cannot help but notice its relation to the dependence of modern states on electricity and fossil-fuel based energy and the implications this has on our planet's environment. Relating energy and Anthropocene, anthropologist Bruno Latourmakes a caustic remark- "With its increase in energy expenditure, human civilization now "runs", so to speak, at seventeen terrawatts, twenty-four hours a day, which ends up making it comparable to the expenditure of volcanos or tsunamis- obviously more violent, but over short periods of time.” (Latour, 2018:115)

This intensity of the impact of our high demand for electricity is felt by academics of related disciplines as well. The historian Dipesh Chakrabarty has shown that Anthropocene calls for a rethinking of history and he also explicitly takes into account the implications of fossil fuel based energy use and its relation to global warming. (Chakrabarty, 2009) In her articulation of the term Anthropocene and in proposing alternative concepts, Amercian anthropologist Donna Haraway also points out in a rather rhetorical articulation of the relation between fossil fuels and its future devastating implications for "fossil-burning human beings seen intent on making as many new fossils as fast as possible.” (Haraway, 2016) The rapid loss of bio-diversity that the Anthropocene entails troubles her, as well as many of her fellow colleagues, who are intent upon mapping out a way of living more sustainably with all the existing earth beings. (Tsing, 2017)

The thrust of the Anthropocene discourse has also revived the subject of energy within the arena of anthropological research. Energy is being viewed as one of the crucial nodes of the current environmental crisis and its different manifestations in different societies urgently call for the attention of anthropologists, who have responded accordingly starting from early in the 2000s. This new of body of environmental research focuses on both the cases that involve fossil fuel related problems in different countries, as well as those relating to renewable energy sources (High, 2019). While the issues surrounding fossil fuels such as oil, coal, gas can be many (extraction, distribution and use), from an early period anthropologists paid particular attention to the impact of power plants and resource extraction on the local population, especially indigenous people. Resistance to power plants and companies are fairly common phenomena as the conditions for mining them are often harmful for the local population (Boyer, 2014).

In Bangladesh, energy issues have received attention mostly from a political perspective rather than sociological. Although some work has been done from a justice approach (see Luthfa, 2019), anthropologists have rarely approached the subject with in-depth conceptual analysis of the problems arisen. The present work is meant to complement this gap by taking into consideration a debate that broke into the political scene of Bangladesh, revolving around a particular power plant and the perceived threat it poses for a mangrove 
forest, the Sundarbans. That movement that ensued continued under the banner 'Save Sundarbans', demanding termination of the coal powered plant, the Rampal power plant. In course of this movement, both parties invoked arguments for and against the plant, both vying to justify the legitimacy of their respective positions. This discourse, which took an elaborate shape in 2016, revealed the important values of both groups which came into play during the movement. While the government espoused a pro-development strategy, those rejecting the power plant were explicitly pro-environment. Their environmentalist discourse as well as the economic growth centered argument of the state is the subject of analysis in this research, with a specific attention to value theory. The mode(s) of environmentalism espoused by the environmental groups or activists are evaluated to bring forth their inherent approaches regarding energy and the forest at stake.

\section{Conceptual Framework:}

The recent developments in the field of energy research within Anthropology guide this study. In the face of the aforementioned Anthropocenic reality, energy in Anthropology is discovered to have a major conceptual gap. The third generation of anthropologists who have approached energy related issues with much enthusiasm were required to address this lack of particular theoretical articulation (Szeman, 2014) and in the process proposed some concepts with potential impetus to serve as a framework for viewing these issues. Although energy issues are often closely related with existing power politics, researchers often tended to disregard such affiliations. However, new research concerning energy is eager to meet these challenges head-on, as concepts such as 'energo-politics' or 'energo-power' (Boyer, 2014) are proposed to deal with the intricate realities that are invoked when energy, politics and power meet. Energo-power, essentially, is the conceptual frame that "rethinks political power through the twin analytics of electricity and fuel”. (Szeman, 2014)

This is certainly not the only volume of works that emphasize the importance of studying electricity and its social impacts. In recent years, electricity as a subject of inquiry has also gained attention among anthropologists. In a collection of essays titled 'Anthropology Electric', this issue was taken up by several academics. These essays, as Dominic Boyer demonstrates, bear evidence to the conceptual potentials of 'Anthropology electric' (2015), one that seeks to understand the workings of electricity and its elaborate infrastructures in the modern society, without electricity whose very existence would be impossible. Indeed, like air, its presence and significance eluded social scientists even until recent times. Electricity, harnessed from a variety of carbon, renewable and nuclear sources, is also generally neglected in social theory and cultural studies.

Although late, the authors in this volume raise some important points, one such of relevance is Akhil Gupta's argument that the Global South should fuel its path to development in a 
different manner than the North has done in the past, noting- "In the Anthropocene, the issue of how we use energy is one of the central questions facing humankind. Which energy sources we use and how much we use will determine the rate of climate change.” (Gupta, 2015) Gupta urges that the energy mix of the developing nation-states becomes more inclusive of non-carbon renewable resources like solar, wind and hydropower, which will necessitate smaller grid-networks of electricity rather than reproducing the ever-widening central grids that cannot cater to most of rural populations and marginal urban people, anyway.

Such propositions are noble, but in reality their merit hardly recognized as the central grid, fueled by carbon based energy, foreshadows the development oriented economies of the globalized world. Boyer elucidates this point well in terms of grid logic- "Nonnuclear, lowcarbon energy transition is a threat to grid. Wind and solar energy sources are intermittent and most effective for hyperlocal use. They are thus feared as agents of de-growth and grid disintegration..." Thus the grid is recognized as a major agent in propelling the neo-liberal economy that emphasizes growth in wealth and encapsulates an ideology of 'more' while rejecting or minimizing its responsibilities in mitigating environmental damages.

It is within such socio-political trajectories that the possibilities of energy transitions traverse, and we find that having alternative solutions to a crisis at the doorstep is often not convincing enough. Because the way we perceive them and value their significance can differ radically. In her early work among the energy policy makers in the USA, Laura Nader shed light on this in several of her works on energy. In her 2004 article, Nader pointed out how the world of energy scientists is ruled by a unilinear development model reliant upon unrelenting ideas of scientific progress that views alternative energy sources with caution and fear, entailing in their eyes, complete lifestyle changes. (Nader, 2004)

Indeed, different energy sources implicate different political visions involving different ways of valuation of our present reality as well as future possibilities. Such values, attached to energy related endeavors, are embedded in the history of modern statecraft, political alignment or culture. On the other hand, environmental values can also differ in terms of perception of environmental issues, goals of environmental action, methods of pursuing those goals. However, most environmentalisms (plural because they vary for above mentioned reasons) support sustainable energy sourcessince environmentalists in general are against high carbon emissions that fossil fuels produce.

To examine the valuation of a particularly contested power plant and its hostage, as if, a forest, a look at the value theories in the social sciences is beneficial. Discussions regarding how and why we value certain things individually or holistically, i.e. theories of value, entered the social sciences via German philosophy of the $19^{\text {th }}$ century. In anthropology, 
theorization of value has seen some turns, but as of yet, there are broadly two theoretical strands in which researchers belong- structural analyses and action-oriented analyses. (Robbins, 2016) In the first school, anthropologist Louis Dumont's name comes to the fore, Dumont almost single-handedly restored value to the core discussions of anthropology.

As a structuralist, Dumont saw values as embedded in different ideological 'levels' of culture, and as essentially hierarchical. He showed that cultures have one 'supervalue' or 'paramount value', where all other values are maintained to realize this core value. His famous example of such a paramount value was that of 'purity' in the context of caste system of Hinduism in India. His view of value systems can thus be called monist, as opposed to the pluralist approach to values. This dichotomy of Monism and Pluralism is inherited from the value theories in Philosophy (Robbins, 2013). Pluralism maintains that more than one value can be dominant in a society and such values often struggle with one another. Max weber was one of the early social theorists to endorse pluralism, putting forward a typology of spheres of activity that he felt exists in societies, namely- economic, political, religious, intellectual, erotic and aesthetic. These spheres and their associated values, he stated, could be contending with one another, ending up in "irreconcilable conflict” (Weber, 1946).

These concepts of value pluralism and monism and the idea of 'supervalue' well resonate with the subject matter at hand. However, how particular values become so important and new values are created and endorsed by collectivities of people, remain the concern of yet other theories of value. In this regard, the action-oriented theories may prove helpful. This lineage of theories views values as products of human action and labour (Turner, 2008) and acknowledges that values can take the shape of material 'value-forms'. Such idea of valueform can help us understand why particular things become irreplaceable in our imagination so that we get involved in struggles over them, while other things relegate to secondary places.

To study the particular form of environmentalism at play in relation to the movement that followed, it is necessary to look at the types of environmentalisms existing in the global environmental discourse. Kay Milton, who defined environmentalism for anthropologists, tells us that there are three major forms of environmentalist discourse present in the contemporary world- globalist, anti-globalist and radical (Milton, 2004). The globalist discourse is propagated by global organizations such as United Nations Environmental Programme, World Commission on Environment and Development (WCED, now Brundtland Commission), IUCN (International Union for Conservation of Nature), nationstates and NGOs with environmental interests. This discourse is, as its name suggests, global and sees environmental problems as planetary that must be solved with concerted 
centralized efforts of governments worldwide. It seeks to promote sustainable development and is anthropocentric in orientation.

The anti-globalist perspective on environmentalism rejects such modernist endeavor from the outset. It originates from the world-systems theory and criticizes the colonial forms of globalist projects in the Global South. It resists the 'growth' centered activities of a global economy that often works at the expense of local communities and their traditional ways of living, incorporating them in the new economy in various ways. Neither does this sort of environmentalism believe in global solutions to the environmental problem, since it scrutinizes its emphasis on 'sustainable development' to begin with, viewing it as part of strategies of the North to dominate the Third world countries. (Milton, 2004)

The third perspective active in the global environmental discourse is the radical one. Unlike the other perspectives which are human-centric in their values and objectives, the radical environmentalism is grounded in 'deep ecology'. Deep ecology is based on the respect for ‘the life community' (not just sentient beings) and holds that- “....all living things are alike in having value in their own right over and above their use for humans, and that humans have no right to reduce the diversity of life forms except to satisfy vital needs.” (Kalof and Satterfield, 2005)

Radical environmentalism is then essentially eco-centric that, as Milton so effectively summarized- "recognizes the intrinsic value of all natural entities, human and non-human animals, plants, landscapes, ecosystems, the planet as a whole...”. Ecocentrism began in seeking to protect the environment from development, rather than seeing it as an object of conservation that serve human development in the long run. (Eckersley 1992, in Milton 2004)

Understanding a movement and the value-laden discourse it invoked, as well as the resistance it faced from the authorities, intent upon launching the power plant at any rate, together these concepts lend a more elucidative lens, one that sees the values related to the particular politics at play and pays attention to the complexity of these oppositional positions.

\section{Research Methodology}

Inquiring into the basic assumptions and the dominant values underlying the respective positions assumed in the debate surrounding the power plant under question, requires employing the well-known method of discourse analysis. This mode of analysis originates from the broad method of textual analysis that diverged and took the shape of different forms of text analyses in various disciplines, including content analysis, rhetoric analysis and ethnographic analysis (White \&Marsh, 2006). Discourse is a systematic way of representing social reality in such a way that meaning is ascribed to that social reality. 
Fairclough's (2003) articulation of discourse analysis involves careful consideration of power and ideology associated with discourses and his prescribed method is hence suitable for this study.

Texts have external relations to other texts, something that has been called intertextuality by Fairclough. In addition, and relation to this, texts also have implicit assumptions and presumptions. The assumptions of texts are tied to certain ideologies, especially when it comes to discourses in the public sphere. The public sphere is defined by Habermas (1984) as ' ...the domain of everyday living in which people can deliberate on matters of social and political concerns as citizens, and in principle influence policy decisions.' (Fairclough, 2003: 44) And according to Arendt, whom Fairclough is following in articulating public sphere- action and discourse go hand in hand in the process of change-making within this domain. Related to the idea of public sphere is also the matter of universality and particularity, that is- 'how particular identities, interests, representations come under certain conditions to be claimed as universals.' (Ibid., p.40) This is deeply connected with the question of hegemony.

Gramsci's concept of hegemony involves the maintenance and deployment of power (through politics) by certain institutions and groups, by means of gaining popular consent of the masses. Ideologies are mechanisms for gaining such consent or trust of the public that in turn preserves the existing power relations. As such, political forces can contend to uphold their certain visions of the world and proclaim their universal status in related discourses. Critical discourse analysis is then an essential method to unpack the public debate about the Rampal power plant. The assumptions and intertextuality within these discourses, from either side, allude to certain ideologies of development and environmentalism that are underpinned by respective values and visions for the future.

For analyzing these discourses, interviews found on print and digital media were purposively selected for this study. These interviews were conducted by different print and online media representatives, the timeframe of which begins from 2016 when the movement gained momentum, till date. Also included were findings of recent researches done by anthropologists on energy plants in Bangladesh. Alongside them I have used information on the energy scenario on Bangladesh that has been drawn from multiple reports, both by national/state and international agencies. This information is used to conjure a tangible backdrop for making sense of the discourses around energy, environment and development.

\section{The Energy Scenario of Bangladesh and the Rampal Coal Plant}

Bangladesh's drive for development, indexed in the GDP indicators of its economy, requires that the country produces more energy than ever before. In its pursuit of economic 
growth, the country has been seen to hold record in GDP growth rate in the past 3 years, and currently holds the second-highest growth rate in South Asia. Production at this rate is predicated on an increased rate of energy generation and use, which can be demonstrated by a combined look at the GDP and energy consumption rates in 2018- "In 2018, while GDP rose by 7.9 percent, primary energy consumption increased by 8.6 percent over 2017.” (Ichord, 2020)

The energy mix by which this was achieved is dominated by fossil fuels, as in most countries. Natural gas is the most significant source of energy production, Bangladesh having its own gas fields. However, for extraction and production of gas from the fields, Bangladesh relies on foreign investors, like Chevron, which works under contract with PetroBangla, the national oil and gas operator. But the total energy demand can hardly be met by gas alone, and the second biggest source of power for the country is oil. This resource is not available onshore so much in Bangladesh, butin the face of pressures by World Bank "to outsource a substantial portion of the state-owned energy sector" (Mirza, 2020) and the growing energy demand during 2009-10 that the government was struggling to meet, the state was compelled to move toward petroleum based quick rental fixes to address the power problem.

Although this helped meet the electricity supply gap, the rental system which is run by private companies incurred subsidy-driven fiscal losses amounting to USD 4 to 4.5 billion. These costs would have been enough to generate electricity in alternative methods, e.g. building and repairing gas plants, managing system loss (Rahmatullah, 2011 in Mirza, 2020). As Mirza's work further shows, such choice by the state is not only driven by its energy interests, but rather reflects the influence of business groups and political connivance in a neo-liberalized reality.

The third type of fossil fuel based plants, the most contested among all three are coal based power plants. Bangladesh's power system master plan, designed by the Japan International Cooperation Agency (JICA), envisions obtaining 40 percent of energy from coal (Master Plan, 2016). These plants are planned to run on imported coal from India, China and Japan and currently two of them are being built in at Rampal and andPayra, both with the capacity of 1320 Megawatts (Ichord, 2020). At present, five coal plants are undergoing preparation and construction phases, one of which is the Rampal power plant. The plant was proposed to be built in Rampalupazila in the Bagerhat, a district placed in the south-west of Bangladesh. The plant is to be developed by the joint venture company called 'Bangladesh India Friendship Power Company’. The Rampal plant was approved in 2013 for construction, but was faced with local protests against it, on ground of its location being too close $(14 \mathrm{~km})$ to a critical environmental zone- the mangrove forest of Sundarbans. 
Identified as one of the largest mangrove forests, the Sunderbans is known as home to the beloved tiger species- the Royal Bengal Tiger, as well as a plethora of animals and plants. It should be mentioned that, this is not the first time the forest has faced threats to its existence. Shrimp-farming, a profitable livelihood taken up by the local people in areas of Bagerhat, Satkhira, and encouraged by the state as it contributed substantially to the country's export income, has been a reason for gradual decimation of the forest in the past decades. (Hossain, 2001) Experts have warned that if such developments continue unbridled, Sunderbans will face the same reality as another mangrove forest in the country, the Chakaria mangrove forest in Cox's Bazar which was eventually destroyed due to shrimp-farming and over-exploitation by unsustainable human activities.

Aside from fossil fuel based power generation, Bangladesh is trying to include more renewable energies in the mix. From an early time, the country was getting some of its energy needs met by Hydropower plants, but the amount of this energy is a small proportion of the total power generation (less than .1\% in 2019). Therenewable non-carbon source given importance so far is solar, with one $28 \mathrm{MW}$ photovoltaic project being built in Teknaf, Cox's Bazar. However, the goal of Vision 2021 of achieving 10\% energy through renewables seems far ahead still, since until 2019 the total generation from these was 4 TW, one of the least in the Asia Pacific. (bp Statistical Review of World Energy, 2020) However, electricity generation of the country has been on the rise for the past 10 years, growing at a rate of $9 \%$. This electricity, as the power mix shows, is mostly produced from carbon-based fuels.

\section{Analysis of the debate:}

The plant under construction in Rampal was proposed as early as 2010 and is to be of 1320 MW generation capacity. The plant will run on imported coal from India, with whom construction work and financing of the plant is jointly shared. From the beginning of the announcement of the power plant, it has faced with protests based on its particular position near the largest mangrove forest of the Sundarbans. Indeed, the location incited a rigorous debate between the government and a cluster of intellectuals-activists-environmentalist groups and individuals. Among the groups against the plant, most influential was the coalition called National Committee of Bangladesh (NCBD), a coalition of left-leaning groups, intellectuals, activists and politicians. Several points have been raised in regard to the types of possible damages that could be incurred by the plant after its establishment, which is envisioned to go into power production from 2022. Below are the major points of contention between the pro-plant and anti-plant groups, with the specific logic they produced in defense of their respective stances in regard to the Rampal coal powered plant. 
Environmental Impact Assessment (EIA): Before every major development or industrial projects, environmental impact assessments are done to examine if the project under consideration will significantly affect its surrounding environment. The EIA of Rampal power plant has been criticized by environmentalist intellectuals and activists on various grounds. In an interview with The Daily Star on September 1st, 2016 Dr. Badrul Imam of the Department of Geology, University of Dhaka, mentioned the basic fault of the EIA of the project that it was done a year after the land was acquired for the project, rather than before as is standard procedure (Imam, 2016). This, Imam pointed out, renders the EIA as inefficient as an 'eyewash'. Dr. Imam had proposed an alternative spot for shifting the plant away from present location of Rampal to another prospective site just $10 \mathrm{~km}$ further away in Labanchara (24 km from the Sunderbans). This place was also suggested in the EIA as an alternative site to Rampal for the project. However, the plant location was never shifted from Rampal, despite these pledges by intellectuals and environmental activists. The reason for not shifting the place has been a subject of much discussion on this topic, although the government showed no interest in acquiring another stretch of land for the power plant. From the government's side, the explanation for such a decision was given as solely based on land shortage for such projects. (Hossain, 2019)

Apart from this, the EIA was also found "grossly faulty" upon perusal by scientists, as was claimed by another civil intellectual, environmental attorney SyedaRizwana Hasan in an interview on September $6^{\text {th }}$, 2016 with the Daily Star. Hasan told the Star that she had sent the EIA to her peers who work in the EIA Resource and Response Centre of India. They found that "the EIA is grossly deficient and faulty on major accounts that include cumulative impact assessment, study on radiation, quantitative assessment, proper and effective public consultation, site selection, coal source and so on.” (Hasan, 2016) With regard to assessments, it is also mentionable that the UNESCO asked the state to do a thorough environmental assessment of the south-west region of Bangladesh, including the Sundarbans. (Roy, 2018) This assessment, however, is yet to be done as of June, 2021.

Emission reduction technology of the plant: The EIA of the plant suggested that it would use super-critical technology (SCT) in the coal plant to minimize the carbon emission. However, the environmental group quickly pointed out that it would not reduce emissions significantly enough and still harm the environment in and around the mangrove forest. This was taken upon by the authorities seriously who then claimed to use Ultra Super Critical Technology of USCT in the plant that would reduce emission by $40-45 \%$ than less refined coal plants. The current state of the plant is said to incorporate this technology which, the Director General of Power Cell in Power Division, Mohammad Hossain has said to have incurred additional costs to the plant construction budget. This development in the 
plant however, is deemed to be insufficient by the anti-Rampal groups, as there would still be significant carbon emission in the region near the ecologically sensitive forest zone. Still, some groups, such as PoribeshBachaoAndolon (Save the Environment Movement) see this as a small victory over government obstinacy. (Shitu, 2021)

Coal ash: The power plant is estimated to generate ten lakh tonnes of ash every year for the duration of its active period of time. Initially it was stated by the EIA that the ash would be kept in a 100 acre- pond before selling them to brick kiln and cement manufacturers. Under pressure from environmentalists the government later revised their arguments in line with this aspect. As one statement by the state minister follows- ""Modern ultra-Super Thermal Technology would be used in the plant, which will prevent emission of harmful dark smoke and ash. While transporting to the plant the coal will be covered. So water or air will not be polluted. The water will be processed through improved technology. No polluted or hot water will be discharged to the river. A small portion of the water of River Pashur will be used, which in no way will affect the river." (Noor, 2015) Intellectuals and experts pointed out in turn that keeping such a huge amount of ash near the Passurriver that flows through the forest is disastrous (Imam, 2016). This is because there are chances of flooding and also seepage into groundwater of toxic materials like lead, mercury, arsenic, chromium in case the pond lining is compromised. And despite reassurance by government agents, there is also a pertinent concern among environmentalists about fly ash, which will be produced in huge quantities. Fly ash is one of the reasons one of the coal plants in Orissa, India was turned down for fear of damage to agricultural lands. Ash pond management has also been a source of concern and protest in case of Indian coal power plants which faced with strong opposition in several regions of the country. (Hasan, 2016)

Water pollution: As the minister's claims suggest, there were also qualms about water pollution. The coal for the plant will be imported from India through the waterways of Passur River, the river that crisscrosses throughout the Sundarbans. Given several occurrences of ship-sinking into rivers while transporting oil or coal, including the Passur river in the past decade, environmentalists have raised their concerns regarding the possible hazards that this transportation of coal and unloading of it may incur. The aspect of water pollution has been highlighted greatly in detailing the plant's future influence on the waterbodies surrounding the Sundarbans. Anu Muhammad, a professor of economics in Jahangirnagar University and member-secretary of the National Committee, expresses his concerning regarding this in an interview- "The Sundarbans, the largest mangrove forest in the world, largely depends on water. It is alive because of its water bodies -- rivers, canals and tributaries. If water is contaminated at one point, the entire forest would suffer. We have reasons to be concerned. We have enough scientific evidence that the coal-fired plant 
in Rampal and many business projects inspired by this will kill the forest." (Muhammad, 2016)

There are also concerns about the usage of water from the river and discharge of effluents from the plant after processing. Although the government has consistently assured that the amount of water taken from the river will not be significant, and the waste water will be properly treated before being released into the river, this has not convinced the environmentalists who have pointed at the long track record of negligence by state agencies and their inefficacy in preventing liquid waste disposal by industrial bodies into rivers in the past decades. (Imam, 2016)

Threat of bio-diversity loss in the Sundarbans: One of the main drives in the movement against the plant has been the threat it poses to its unique ecosystem and the bio-diversity of the forest that is in one estimation, only $4 \mathrm{~km}$ from the plant site. Environmentalist groups have actively protested against the plant on the grounds of severe risk of water, air pollution in the areas surrounding the mangrove forest. The fact that the forest is a World Heritage site, being the single largest patch of mangrove forest in the world, has contributed greatly to the force of their active protests. This is apparent in the iconography of the posters, banners used during the movement, both electronic and tangible, as well as the immensely creative cultural expressions of the protest manifested in songs, documentaries about the movement. These revolve especially around the imminent threat to the prized species of the forest-Panthera Tigris Tigris, the Royal Bengal Tiger that happens to be the national animal of Bangladesh. The dwindling population of the tigers (less than 200 now in the Bangladesh part of the Sundarbans) has held the attention of environmentalists internationally in the recent decades. While all creatures of the forest, especially marine life in the rivers are predicted to suffer from the plant pollution, the Bengal tiger has been a major force in the biodiversity-conservation discourseof the environmentalists. Causes for this could be threefold- Bengal tiger being the national animal, the most known animal in the jungle, and its special significance for the local people living in and on the forest. The tiger is thus given much importance in the symbolization of the 'Save Sundarbans' movement, which can be seen in the visuals of the posters below. 


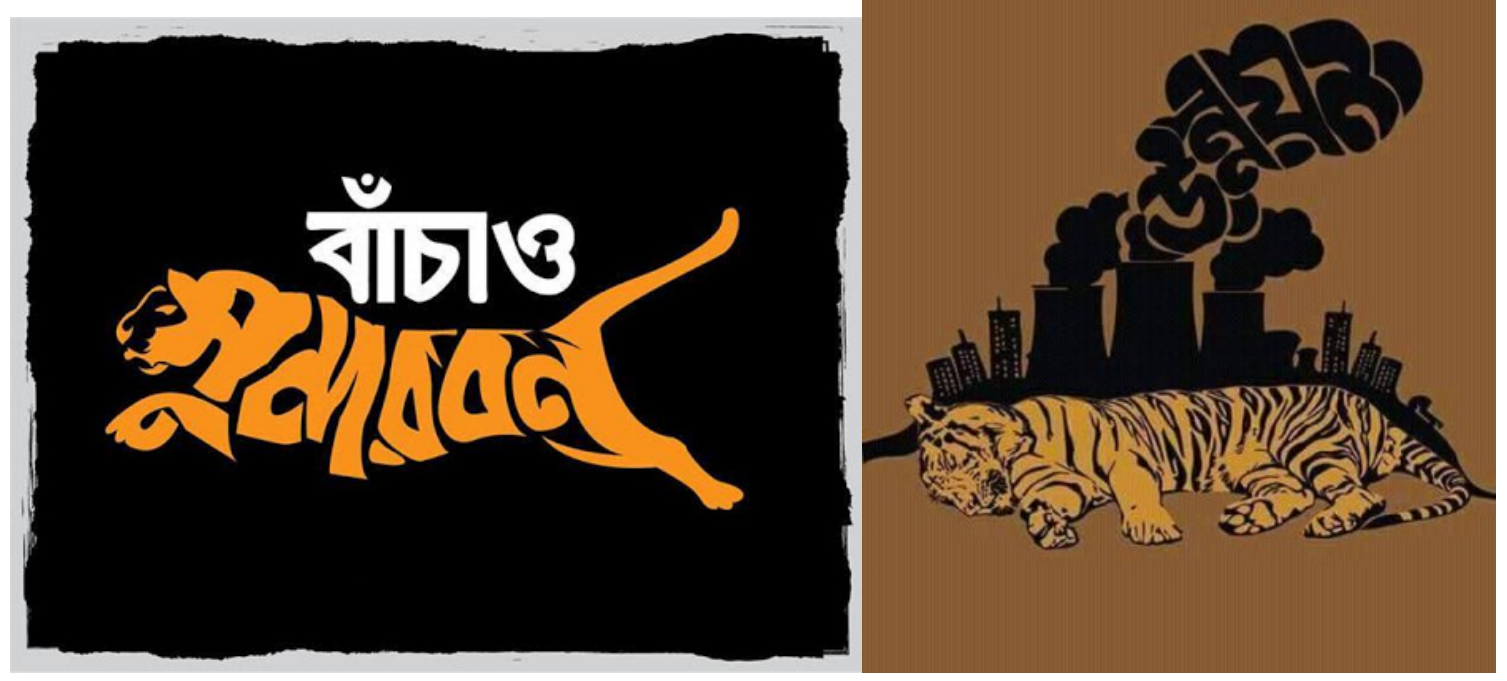

Digital posters made by activists of the Sundarbans Movement. Tigers are a recurring motif.

Apart from the specific species that occupy the environmentalists concern, such as the endangered Irabati Dolphin, the environmentalists also point to the interconnectedness of the multi-species life-network of the ecosystem that will be seriously affected if procedures of the plant go wrong and also indicate the long-term consequences of the consistent pollution in the area that the plant and the numerous industries (over 200 factories are being built near the forest) incited by it will be for forest life. (Roy, 2018) Imam had expressed his concern in regard to bio-diversity in the following manner- "Some people don't seem to understand science. It's a very ecologically diverse place. The smallest forms of lives and organisms are interconnected to the bigger ones. If you destroy plankton, the fish will be affected; eventually the tigers would also be affected."

It has been found by a number of studies that indicate that the local people already feel a change in the number and quality of their catch of fish, crabs and other fauna in the jungle, sensing a gradual decline in the previous vibrancy of forest life forms. (Matin\& Taylor, 2015; Huq, 2020) While this is related to several existing factors, the foremost being poaching of animals, shrimp cultivation, logging, industrial pollution and hazards (e.g. 
cargo ships sinking) and recently, forest fires that environmentalist groups claim are often started by locals to catch fresh water fish, or often by poachers.

The environmentalists make vital points to support their argument to prevent the plant from being built in close proximity of the Sundarbans. After years of protest and pointing out based on scientific logic the pitfalls of the project, the government gave in to some extent, by making changes to fly-ash management and emission reduction technology. The coal transport will be done through closed conveyer belts to avoid spillage while loading and unloading coal. This, however, does not address the concern about capsized vehicles that may cause accidental leakage. Additionally, at the beginning, the project plan lacked a system for collection of toxic sulfer dioxide. This was later included when environmental experts opposing the plant picked this up, causing the budget of the plant to increase by 15\%, according to Mohammad Hossain in an interview with 'The third pole'. (Hossain, 2018)

The location of the place, however, remained a non-negotiable factor of the project. The rationale that was given for this reflected deliberation, although, lacked in clarity. Hossain, in the same interview, mentioned about the scarcity of land for such establishment, while adding the factor of 'over-population' of the country. The prime-minister, in a press conference in 2016 regarding the critique and movement against the Rampal plant, had brought up the issue of the livelihood of the locals in Rampal who were portrayed as if in dire need of employment which would increase in number when the plant goes into construction. This fact is contradicted by Huq's findings (2020) where local people expressed their concern of losing ancestral professions, deteriorating forest environment and an uncertain future.

\section{The value perspective on the energy vs. environment dichotomy:}

What is especially interesting in observing the claim-making and counter-responses of both parties involved in debate- namely the state and the anti-plant environmentalist groups- is the way they perceive each other's views as irrational and negligible. Such irreconcilable conflicts are usually hinged upon different values of the different groups. As per Weber's value theory, which is pluralist, values in a modern society can differ in accordance with different spheres of social activities. If we follow this theorization, the foremost value in the sphere of politics in Bangladeshin recent times has been 'economic growth' and 'development'. Upon close inspection of the present political discourses, one could even argue that 'development' is the 'paramount value', as Dumont proclaimed to indicate the importance of core values, in the national politico-economic endeavors in the country. Economic growth expressed in GDP is another important value of the state. GDP of 
Bangladesh has seen a consistent rise, holding up a record GDP growth rate in the past 3 years, being the second highest among South Asian countries.

But the primacy accorded to 'development' is possibly not just a national phenomenon. This is connected with the global thrust of development, heralded by international organizations such as the United Nations and its associated institutions. In dealing with the environmental issues, these organizations consistently placed a primacy on development over the environment. Remarking on the premium placed on development by these global ogranizations, Kay Milton wrote- "The most striking thing about the above statement is the way in which development, in the form of 'social' progress, 'social' wealth, science, technology and the transformation of the 'human environment', is presented almost as a legitimation of the value accorded to human beings.” (Milton, 2004)

If 'development' is equated with human value in the global discourse, third world governments cannot be blamed for their extra-ordinary drive toward it. In the globalist environmental discourse, sustainable development is the keyword and human poverty is the key issue to address. The governments of the third world countries have their development goals to fulfill and in case of Bangladesh there are also economic goals such as becoming a middle-income country. These are the historical and political conditions that promote the development dynamics and discourses of growth via GDP are taken as affirmation of this development. The fact that sustainability is of secondary necessity to it can be seen in the demonstration of the present case. None of the representatives of the government mentioned here are seriously concerned about the environmental stakes of the said project. The much debated distance has remained a negligible fact, especially when an important step to development (the energy plant) is at stake.

\section{The environmentalist approach of the civil activists:}

If we look at the three modes of environmentalist discourse described before, the environmental values of the protesters and anti-plant groups seems to belong to not in the anti-globalist discourse or the radical discourse, but to some extent to the globalist discourse. This can be seen in their reluctance to oppose coal as an energy source in general and their dependence on scientific data in presenting their case against the plant. Their globalist approach is also apparent in their appeal to UNESCO to save the forest from the damage from the particular power plant. UNESCO however, also postponed their action against the plant and has refrained from putting the site on the list of 'World heritage in danger' although claiming to put it in the said list for the past couple of years.

However, there are individuals within the protesters, as well as energy experts, who have pointed out that coal as a source of energy is quickly running out of time, and therefore in 
the coming years will not remain a cheap source of electricity any more. (Ichord, 2020; Imam, 2016; Hasan, 2016) Alternatively, organizers of the movement have often refrained from revoking coal altogether and stayed focused on the Sundarbans only. The accusation of being 'anti-development' was frequently hurled at them, as a result the protesters and intellectuals sometimes opposed this accusation by saying that they do not challenge the development project of the state (Imam, 2016; Muhammad, 2016). Such claims portray the profound hegemonic power of the 'development value', and the non-negotiability of it at least in the public discourse. Here I would argue that the protesters' outright rejection of coal as fuel for economic growth would make the movement a radical one. While many posters and slogans bore a strong opposition to coal during the movement, in case of the Rampal plant only the forest environment and those living around it were highlighted and a general rejection of coal on part of the protesters is often avoided in official statements and interviews. One could make further assumptions about the lack of strong local participation in the movement from the background of the land dispossession of the poor in Rampal for establishing the plant, which in many cases was forceful. (See Mahmud et. al, 2020; Islam \& Al-Amin, 2019)

There are undertones of 'deep ecology' in the protesters' articulations of the possible effects of the plant on the Sundarbans. In the environmental discourse of the anti-power plant movement, the phrase 'life-nature' (pran-prokriti) was frequently used to express the protestors' concern for the flora-fauna of the forest environment. The environment-people nexus is rightly understood by some (Imam, 2016; Muhammad, 2016), although the overwhelming use of the scientific language was a barrier to communicating with the local population living near the Rampal site, as Huq finds in her study. However, Huq also notes that the local people possess an understanding of this connection between 'development' and 'environmental change' and are wary of future heavy industrial endeavors. But they were cautious in their action against the power plant and were ultimately, dependent on the civic movement and its associated urban protesters who are championing their cause in the national and international arena.

It is within this scenario that we look at the mode of environmentalism at work in the case of Sundarbans-Rampal power plant movement. If we look at Milton's typology, it is clear that the movement under discussion is not globalist in its approach, as globalist environmentalism ultimately support economic growth; growth has no alternative in the globalist model of environmentalism. But many proponents of the movement were explicitly critical of the 'growth' perspective as a catalyst of environmental degradation and pollution (Mirza, 2021). However, this comes into contradiction with the claims of the protesters who say they are not against 'coal' or 'development' of the country per se. 
Clearly, the civil intellectuals who make such mixed statements have a different understanding of development itself. In their criticism of the current state approach to development, they have pointed out repeatedly that the development model solely focused on GDP growth is too dependent on infrastructure building and industrial flourishment. Sustainable development model, one that pays attention to the environmental impacts of development endeavors is pursued only superficially, critics claim.

The partial endorsement of fossil fuels by the majority of activists is an indicator, added with some others, that the environmentalist approach at work here is not entirely ecocentric, i.e. radical. This is also apparent in their promotion of the Sundarbans as a valuable resource for Bangladesh. The reasons accorded to preserve the forest are two-fold. First, the Sundarbans acts as a protective shield that guards the disaster-prone coastal belts of Bangladesh. Secondly, in a similar vein, the status of the Sundarbans as a natural heritage site is alluded to as a cause to protect the forest. Protestors, national and foreign allies including, have also used this status as a means to halt the plant establishment by appealing to the UNESCO to protect the forest from the threats the plant poses to it. However, despite theirrepeated appeals the proposal to review the status of the forest as an endangered heritage site keeps being deferred. (Daily Star, 2021)

One of the basic tenets of eco-centric (radical) environmentalism is that this approach does not view the environment and elements of it as resources for human use and does not value them for this merit only. According to those who adhere to this perspective, nature and other earth beings deserve to survive and live well in their own right and retain their intrinsic values beyond their 'services' for humanity. In this sense, it could be said that in terms of value, eco-centrism is apparent in the mix of environmentalist discourses regarding the Sundarbans. Strategically, eco-centric or radical environmentalist groups are described to be less moderate than globalist environmental organizations, such as they would demand things that might not be readily acceptable by the authorities (Milton, 2002). The means they employ to achieve their goals might also be different from other environmental groups. Radical environmentalist groups are more action-based and creative in terms of strategies to attain their goals of movement. The recent example of this kind is the 'Fridays for future' movement by school-going children, who would strike for one day a week for voicing their concerns for the changing climate and the consequences for their future.

The 'Save the Sundarbans' movement is, despite its eco-centric undertones, not radical. This is evident in the lack of unity in outright rejection of coal and other fossil fuels, as well as their presentation of the Sundarbans as a valuable resource for the protection of coastal zones. However, eco-centrism is still upheld as an important value by the protesters, as will be apparent by the songs, slogans written by activist-artists and posters drawn to express 
their concern and care for the forest animals and trees. The movement is not entirely globalist, since its associated activists expressly critique the aggressive development agenda of the government, but neither is it anti-globalist, as the content of their argument in the case of Sundarbans is not about the distribution of the rights of forest management. In fact, there is a lack of critique of globalization and industrialism in relation to the case of Sundarbans among the environmentalist discourse of the activists. Heavy industrialization and salinity rise around the forest areas were noted, as mentioned before in this article, for decades preceding the movement. And yet, it is only after the power plant was announced that the activists recognized the move 'as a final blow' to an already ailing ecosystem. Industries mushrooming in the surrounding area, although recognized as a serious threat to the forest, do not receive as large a place in the discourse as the power plant.

Having over-lapping approaches of environmentalism is nothing novel; it has been seen in case of past environmental actions and movements. In evaluating the environmentalist approach of the Sundarbans movement we can see a similar over-lapping of eco-centric and globalist approaches. Despite having an eco-centric bent, the movement remains to an extent globalist. In emphasizing the importance of the Sundarbans as a natural resource for the country for protection from cyclones and other disasters (The Wire, 2020), appealing to an educated, cultured populace as well as a global audience, and in refraining largely from rejection of fossil fueled power plants- the movement conforms to the globalist mode of environmental discourse.

\section{Energy politics in light of the value theories}

In her 1981 essay published in 'Physics today', Laura Nader expressed her grave concern about the lack of thinking alternative sustainable energy solutions in the USA. The problem arises from a want of interest on part of energy experts in renewable technologies such as solar, rooted in government's apathy toward these technologies. Nader saw the importance of values in the case of energy problems, noting explicitly- "The coming era will require practical, general, earthy types of thinkers who understand conflicting value systems... The energy problem is not a technological problem. It's a social problem.” (Nader, 1981)

This article emanates from the author's intent to project the particular movement and the power plant at hand through a framework of values. The 'irreconciliable conflict' that we see in the case of the Rampal power plant case makes sense from a Weberian point of view. The Weberian stance in regard to values is tragic and existential in nature. (Lassman, 2011) Value monism, according to the pluralists is not sustainable because such a value system, while purportedly harmonious, is essentially totalitarian. From a pluralist stance then choices have to be made when conflict between different institutions or parties with differing values arise, "that will result in realizing less of one or the other value" (Robbins, 2013). 
Determined to join the ranks of a middle-income country status and achieve the development goals of Vision 2021 followed by the government, there is an overwhelming emphasis on GDP growth in current economic policies of Bangladesh. How the concept of GDP growth became crucial to the development plan of Bangladesh will require a long look into the country's development history, its relationship with international debtor institutions such asIMF and World Bank and its extent of compliance with the development goals of the United Nations. This will require an in-depth investigation into the causes of the drive for higher GDP growth. However, the need for economic growth is a recognized facet of the country's development process, one that has been repeatedly scrutinized for being industrydriven and oblivious to people's perils and environmental risks. (Mirza, 2019)

According to political theorists like Berlin and Rawls, modern liberal politics is driven inevitably by plurality of perspectives that are often embedded in the pluralism of values. Peter Lassman describes Isaiah Berlin'sstatement about this as follows- "he states that, if there were no discord or conflict about ultimate purposes, then there would be no need for politics and, therefore, nothing, strictly speaking, for political theorists to talk about." (Lassman, 2011:7) Theorists of pluralism therefore view disagreement and difference of opinions as an integral part of the politics. Disagreements lead to political negotiations and ultimately result in modifying the extent to which the goals of each party are realized. Hence from a pluralist point of view, both economic and environmental values are competing in the energy scenario of Bangladesh and if both values warrant equal significance in the country's plan of development, then energy planning will need to see more adjustments in terms of energy sources.

Bangladesh state had initially planned to include more renewable energy sources into its energy mix, especially to supply electricity to the off-grid areas. While the plan was to cover 10 percent of its energy supply through renewables (Hossain, 2016), this is yet to be achieved in reality. So far, only $3 \%$ of the total electricity production is generated through renewable sources (Uddin et. al, 2018). The distribution of the different renewable sources contributing to it can be seen in the figure below.

Contribution of different instigated renewable sources in Bangladesh (2017)

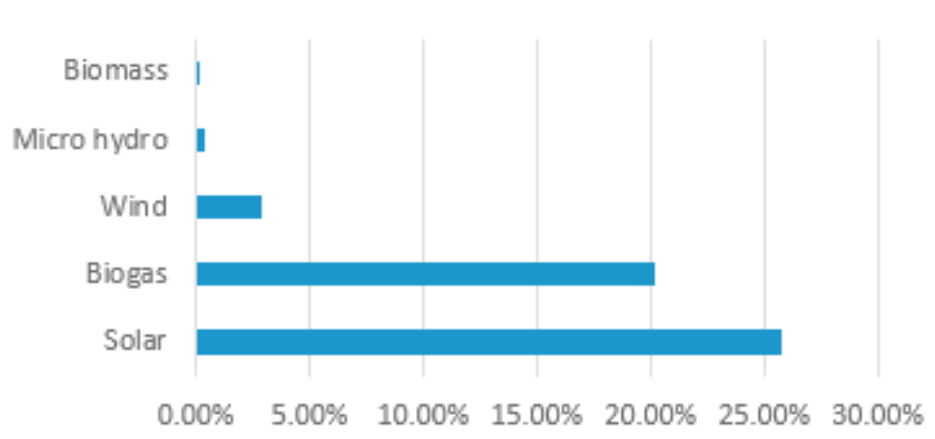

Source: Hossain, 2016 
Albeit growing slow, solar energy has seen some development, being the only source producing significant amount of power (.4 terrawatts according to bp statistical review of world energy, 2020). However, the Bangladesh Power System Master Plan 2016 is heavily reliant on fossil fuels, projecting a plan to reach double the power capacity, 80 percent of which is envisioned to be comprised of fossil fuels such as gas and coal. (Ichord, 2020) The future vision of energy scenario, mapped out by JICA (Japan International Cooperation Agency), shows a heavy reliance on fossil fuels even in far future. (PSMP, 2016:69) Even the best case scenario sees 55 percent use of fossil use by 2041. The premise on which this fossil fuel intensive plan takes shape is dominated by an economic development policy focused on GDP growth and heavy industrialization.

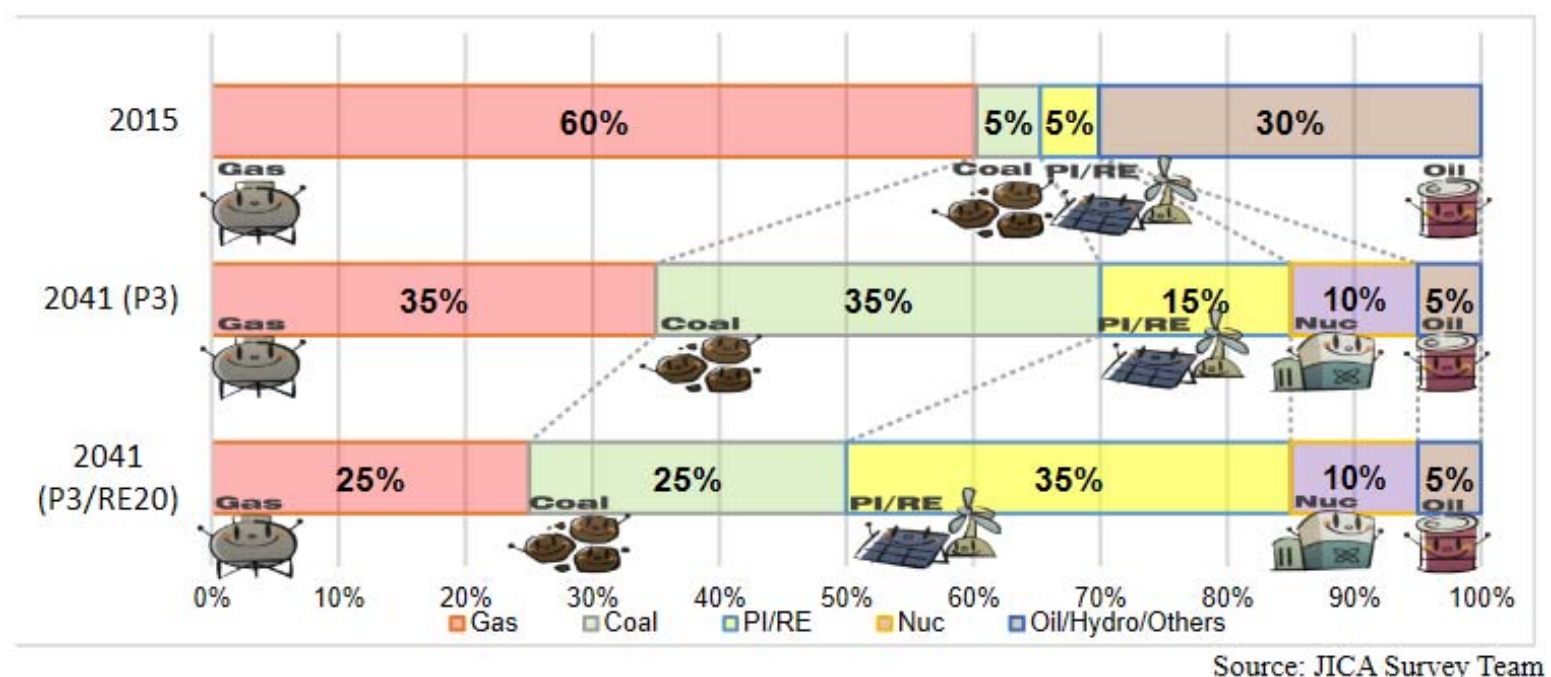

Figure: Proposed forecast of energy mix in Power system master plan, 2016

The state's decision to continue on its fossil fuel reliance has not gone without criticism. However, until recently, the government had strongly defended their position based on the logic of precedence, claiming that industrialized nations such as European countries and USA have consistently used fossil fuels in the past century. (Noor, 2015) Representatives of the government, such as the Director General of the Power cell, have even claimed that coal is a 'clean source of energy'. This sort of claims shows a lack of understanding of the urgency of the climate situation. However, it is only recently that coal is being reconsidered by the government, with 10 coal power plants being scratched, and still five left in the making. (Reuters, 2021) This decision is, as it has been pointed out, not an isolated event. Several other countries in the region, Pakistan, Vietnam for instance, are backing out from building new coal plants.

This shift from coal is mainly sourced from financial concerns, both the government representatives and climate activists have indicated that. (Karim, 2021) Coal may be 
‘clean’, but it no longer remains cheap. Energy analysts like Richard Ichord had warned that coal will become less cheap as carbon taxesplaced on it gradually increase. Similarly, SyedaRizwana Hasan pointed out that financial security for building coal plants may have become constrained which resulted in the withdrawal of the projects. Although the state may want to portray this move as one that is climate conscious, the fact that Rampal power plant remains sustained amongst the five remaining coal plants contradicts such statements.

\section{Conclusion}

This research attempted to take a close look into the energy scenario of Bangladesh, with the Rampal power plant and the environmental movement surrounding the Sundarbans forest it has incited. It studied the values involved in both sides of the debate regarding the power plant and the mangrove forest it endangers. It finds that the movement in its approaches is less radical that it would appear, possibly contributing to its subsequent weakening in the later time of the movement. The case of Rampal/Sundarbans demonstrates that globalist environmentalism may not always succeed in time or may be slower in achieving the goals, as anthropologists recently have predicted.

The author examined the energopolitics of Bangladesh with special reference to a pluralist approach to values. Growth is the overriding value, towering above all others in the Bangladeshi energy scenario. If energy is a principal economic concern, it has also become a political one. In energy, economic values are coopted by politicians to support whichever fuel is convenient to reach set economic goals. In the sphere of politics, we see another kind of values rise- environmental values. Energy is caught between these two kinds of values in Bangladesh, and by extrapolation, to the Global South- economic growth and environmental. In case of Rampal/Maitree power plant, also the political and intellectual or expert domains are seen to collide with the respective value preferences of industrial development and environmental conservation. How this conflict will be resolved is still a matter of choice-making, and so far this choice has been made in favor of the economic domain since the plant still stands to see its opening in near future. Extreme weather events of the recent times- draughts, wildfires in Australia and Italy, flash flood in Germany and frigid cold in the USA (and it continues)- causing damages of life and property, remind us that the time to make different choices is quickly running out.

\section{Bibliography}

Boyer, Dominic. 2014, “Energopower: An introduction”, Anthropological Quarterly, Vol. 87, pp. 309-333

Chakrabarty, Dipesh. 2009, The climate of history: Four theses, Critical Inquiry, Vol. 35, No. 2 (Winter 2009), pp. 197-222

Gupta, Akhil. 2015, An Anthropology of Electricity from the Global South, Cultural Anthropology, Vol. 30, pp. 555-568

Fairclough, Norman. 2003,Analysing Discourse: Textual Analysis for Social Research, London \& New York, Routledge 
Haraway, Donna. 2016, Staying with the trouble: Making kin in the Chthulucene, Duke University Press

Hasan, SyedaRezwana. Sep. 6, 2016, EIA grossly faulty, The Daily Star, http://www.southasianrights.org/debate-over-rampal-power-plant-eia-grossly-faulty/

Hossain, M.S. 2001, Goodbye ChakariaSunderban: The oldest mangrove forest, Wetland Science and Practice, 18(3), 19-22

Hossain, Mohammad. 2016, Achieving sustainable energy targets in Bangladesh, UN chronicles, Retrieved from https://www.un.org/en/chronicle/article/achieving-sustainable-energytargets-bangladesh

Hossain, Mohammad, Sep. 25, 2017, Bangladesh’s power cell DG on Rampal: 'We are introducing coal when it is no longer dirty’, Interviewed by Chowdhury, K.R, The Third Pole https://www.thethirdpole.net/en/energy/bangladesh-has-limited-options-except-coal-basedpower/

Huq, Moshreka Aditi. 2019, The Significance of Civil Intellectuals' Activism: A Case of EcoNationalistic Social Movement in Bangladesh, Society, 10, 18, doi: doi:10.3390/soc10010018

Ichord, Robert, F. 2020, Transforming the power sector in developing countries: Geopolitics, poverty and climate change in Bangladesh, Atlantic Council: Issue Brief

Imam, Badrul, 2016, Shift it 10 km away, The Daily Star, Debate over Rampal power plant, https://www.thedailystar.net/frontpage/shift-it-10km-away-1278772

Islam, MdNazrul, and Md Al-Amin. 2019. “The Rampal Power Plant, Ecological Disasters and Environmental Resistance in Bangladesh.” International Journal of Environmental Studies 76 (6): 922-39. https://doi.org/10.1080/00207233.2019.1662183.

Kallof, L., Satterfield, T. (eds.), 2005, The Earthscan reader in Environmental values, London: Earthscan

Karim, Naimul. June 28, 2021, Bangladesh scraps plans to build 10 coal-fired power plants, Reuters, Retrieved from https://www.reuters.com/article/us-bangladesh-energy-climatechange-coal-idUSKCN2E410H

Lassman, Peter. 2011, Pluralism, Cambridge, Polity Press

Latour, Bruno. 2017, Down to Earth: Politics in the new climatic regime, Polity

Luthfa, Samina. 2019, Showcasing environmental justice movements from the South: Comparing the role of media in Bangladesh, Society and culture in south asia, 5 (2), pp. 290-328

Mahmud, Muhammad Shifuddin, Dik Roth, and Jeroen Warner. 2020. “Rethinking 'Development' : Land Dispossession for the Rampal Power Plant in Bangladesh.” Land Use Policy 94.

Muhammad, Anu. Sep. 3, 2016, Risk of losing the Sundarbans, The Daily Star, Debate over Rampal power plant, https://www.thedailystar.net/frontpage/risk-losing-sundarbans-1279825

Matin, Nilufar\& Taylor, Richard. 2015, Emergence of human resilience in coastal ecosystems under environmental change, Ecology and Society, 20(2): 43

Mirza, Maha. Dec. 8, 2019, Pollution grows, death grows, GDP grows (Dushon bare, Mrittu bare, GDP bare), Daily ProthomAlo, Opinion 
Mirza, Maha. 2020, State-business nexus and the quick-rental power plants in Bangladesh, In M. T. Khan \& M. S. Rahman (Eds.), Neoliberal Development in Bangladesh: People on the Margins, Dhaka: The University Press Limited (UPL)

Milton, Kay. 2004, Environmentalism and cultural theory: Exploring the role of anthropology in environmental discourse, Routledge

Nader, Laura. 1981, Barriers to thinking new about energy, Physics Today, 34, doi$10.1063 / 1.2914461$

Noor, AnisulIslamm,27 October, 2015, Rampal Plant Won’t Harm Environment, The New Nation, Accessed December 11, 2021 https://thedailynewnation.com/news/71523/rampal-plantwont-hamper-environ.html

Robbins, J., Sommerschuh, J., 2016, Values, Cambridge Encyclopedia of Anthropology, doihttp://doi.org/10.29164/16values

Robbins, J., 2013, Monism, pluralism, and the structure of value relations A Dumontian contribution to the contemporary study of value, HAU: Journal of Ethnographic Theory, 3: 99-115

Ranganathan, P. May 28, 2020, Amphan in the Sundarbans: How Mangroves Protect the Coast from Tropical Storms, The Wire

Roy, Pinaki. 25 April, 2018, Bangladesh allows nearly 200 pollutant factories near Sundarbans, The third pole, Retrieved from https://earthjournalism.net/stories/bangladesh-allows-nearly-200polluting-factories-near-sundarbans

Star Digital Report, 2021, "Bangladesh gets another year to fulfil Unesco conditions to save Sundarbans”, July 2021, The Daily Star https://www.thedailystar.net/environment/natural-resources/sundarbansforest/news/bangladesh-gets-another-year-fulfil-unesco-conditions-save-sundarbans2135536

Szeman, Imre. 2014, Conclusion: On energopolitics, Anthropological Quarterly, Vol. 87, pp. 453464

Tsing, A., Swanson, H.A., Gan. E., \&Bubandt, N. 2017, "Haunted Landscapes of the Anthropocene” in Arts of living on a damaged planet, Tsing, A., Swanson, H.A., Gan. E., \&Bubandt, N. (eds.) University of Minnesota Press

Turner, Terence. 2008, Marxian value theory: An anthropological perspective. Anthropological Theory 8(1), 43-56.

Weber, Max. 1946, From Max Weber: Essays in sociology. Translated by Hans H. Gerth and C. Wright Mills. New York: Oxford University Press

White, Marilyn Domas, and Emily E Marsh. 2006. "Content Analysis: A Flexible Methodology.” Library Trends 55 (1): 22-45. 